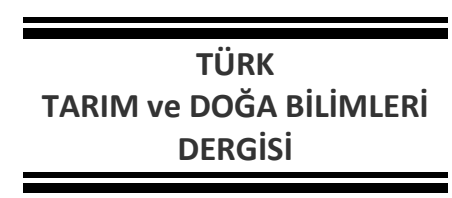

\section{Kadmiyum (Cd) Uygulamasının Tane Sorgumda (Sorghum bicolor L.) Bazı Morfolojik Özellikler Üzerine Etkisinin Belirlenmesi}

\author{
Hava Şeyma YILMAZ*, Kağan KÖKTEN
}

Bingöl Üniversitesi Ziraat Fakültesi Tarla Bitkileri Bölümü, Bingöl

*Sorumlu yazar: seymayilmaz1652@gmail.com

Geliş Tarihi: 27.05.2019

Düzeltme Geliş Tarihi: 27.06.2019

Kabul Tarihi: 27.06.2019

Özet

Çevreye, insanlara, hayvanlara ve bitkilere en fazla zararı olan ağır metallerden birisi kadmiyum (Cd)'dur. Cd'nin bitkilerde meydana getirdiği fizyolojik, morfolojik ve biyokimyasal hasarları belirlemek için yapılan çalışmalar son zamanlarda artış göstermiştir. Bu çalışmada Cd'nin tane sorguma farklı dozlarda uygulanmasıyla bitkinin morfolojik özelliklerinde meydana gelen etkilerin belirlenmesi amaçlanmıştır. Araştırmada; Batı Akdeniz Tarımsal Araştırma Enstitüsü'nden temin edilen üç farklı tane sorgum çeşidi (Akdarı, Beydarı ve Öğretmenoğlu) bitkisel materyal olarak kullanılmıştır. Uygulanan kadmiyum (Cd) dozları (25, 50, 75, 100, 125 ppm) şeklindedir. Çalışma, 2017 yılında Kahramanmaraş Sütçü İmam Üniversitesi Ziraat Fakültesi Araştırma Seralarında 3 tekrarlamalı olarak yürütülmüştür. İncelenen özellikler; bitki boyu, bitki gövde çapı, bin tane ağırlığı, salkım uzunluğu, gövde oranı, yaprak oranı ve salkım oranı olmuştur. Değerlendirme sonucunda Cd dozlarının artmasıyla birlikte, bitki boyunun, bitki gövde çapının, bin tane ağırlığının, salkım uzunluğunun ve salkım oranının düzenli bir şekilde azaldığı gözlemlenirken, gövde oranının ise $\mathrm{Cd}$ (kadmiyum) dozlarının artmasına paralel olarak arttığı belirlenmiştir. Çalışma sonucunda insanlar ve bitkiler için son derece toksik olduğu bilinen Cd elementinin çalışmada kullanılan tane sorgum çeşitlerinin (Akdarı, Beydarı ve Öğretmenoğlu) kadmiyum dozlarından 25 ppm ve üzerindeki seviyelerde olumsuz etkilendiği görülmüştür. Toprak pH' sının da göz önünde bulundurulduğunda hafif alkali topraklar için 25 ppm ve daha yüksek dozlarda sorgum bitkisinin morfolojik yönden olumsuz etkilendiği ve verim amaçlı yetiştiricilik için uygun olmadığı düşünülmektedir.

Anahtar kelimeler: Tane sorgum, kadmiyum, morfolojik özellik.

\section{Determination of the Effect of Cadmium (Cd) Application on Some Morphological Properties of (Sorghum bicolor L.) Grain Sorghum}


Öğretmenoğlu) were found to be negatively affected by cadmium doses at levels of $25 \mathrm{ppm}$ and above. When the soil pH is considered, it is considered that sorghum plant at $25 \mathrm{ppm}$ and higher doses are negatively affected morphologically and it is not suitable for yield purposes for light alkaline soils.

Key words: Grain sorghum, cadmium, morphological feature.

Giriş

Sorgum (Sorghum bicolor L. Moench), Poaceae familyasına ait tek yıllık bir sıcak iklim bitkisidir. Çok eski zamanlarda kültüre alınan sorgum bitkisi, dünyada uygun iklime sahip birçok yerde yetiştirilmektedir. Tane sorgumun, çok kurak ve sıcak alanlarda, mısıra alternatif şekilde yetiştiriciliği yapılmakta olup, mısıra göre fakir ve tuzlu topraklar ile sellere daha dayanıklıdır (Anonim, 1995).

Sorgum dünyada en önemli tahıl bitkilerinden biri olarak beşinci sırada yer almaktadır. Protein oranı mısıra göre daha fazladır ancak sindirilebilir protein miktarı daha düşüktür (Gualtire ve Rapaccini, 1990; Dowling ve ark., 2002). Amerika'da hayvan beslemede en çok kullanılan bitki mısırdır ve sorgum taneleri mısırdan sonra ilk sırada yer alır (Kriegshauser ve ark., 2006).

Ağır metal olarak adlandırdığımız terim esasında fiziksel özellik açısından yoğunluğu $5 \mathrm{gcm}^{3-}$ ${ }^{1}$ 'den daha yüksek olan metaller için kullanılmaktadır. Bunlar içerisinde kadmiyum, krom, bakır, nikel, civa ve çinko olmak üzere 60 'tan fazla metal yer almaktadır. Bu elementler yer kürede çoğunlukla karbonat, silikat ve sülfür durumunda stabil bileşik olarak bulunmaktadırlar (Kahvecioğlu ve ark., 2007). Gelişen ve değişen dünya ile birlikte ağır metal kirliliği çevresel bir sorun haline gelmiştir. Toprak, hava ve su gibi ortamlara ağır metal kirliğinin bulaşma nedenleri arasında; endüstriyel faaliyetler, tarım sektöründe kullanılan gübreler, madencilik, volkanik süreçler, bitkisel üretimde kullanılan ilaçlar, sanayi atıkları gibi etmenler sayılabilir (Stresty ve Madhava Rao, 1999).

Topraklardaki başlıca Cd kaynakları, metal eriticilerden (1000 g/ha/yıl'a kadar) ve $P$ (fosfor) gübrelerinden (150 g/ha/yıl'a kadar) gelmektedir (Alloway ve Steinnes, 1999).

Wierzbicka ve ark. (2007) Cd'nin bitki hücrelerinde, çoğunlukla organik asitlerle detoksifiye edildiğini bildirmişlerdir. Genel olarak, bitkilerin yüksek Cd içeriklerinin sebep olduğu açık semptomlar, büyüme geriliği ve kök hasarı, yaprak klorozu ve yaprak kenarlarının veya damarlarının kırmızıkahverengi renklenmesidir. Kadmiyum fitotoksisitesi, bazı mikro besinlerin normal metabolizmasına müdahale etmenin ötesinde, fotosentez üzerinde inhibe edici etkiler gösterir, terleme ve $\mathrm{CO}_{2}$ fiksasyonunu bozar ve hücre zarlarının geçirgenliğini değiştirir (Prasad, 2005). Bu durum bitkilerin fizyolojilerini etkileyerek morfolojik olumsuzluklara sebep olmaktadır.

Bitkilerin Cd içeriği, Cd'nin insan ve hayvanlara giden yolu olarak büyük önem taşımaktadır. Bu nedenle, bazı bitki türlerinin yüksek $\mathrm{Cd}$ seviyelerine toleransı ve adaptasyonu, çevresel açıdan önemli olmasına rağmen, sağılı riski oluşturabilir. Bu nedenle, özellikle bitkilerde, gıdalarda ve yem bitkilerinde $\mathrm{Cd}$ içerikleri yaygın olarak incelenmektedir (Kabata-Pendias, 2011).

$\mathrm{Bu}$ çalışmanın amacı bazı tane sorgum çeşitlerinin (Akdarı, Beydarı ve Öğretmenoğlu) farklı dozlardaki Cd (kadmiyum) stresine karşı morfolojik olarak verdiği yanıtları belirlemektir.

\section{Materyal ve Yöntem}

Bu çalışma, 2017 yılında, yazlık ürün yetiştirme periyodunda Kahramanmaraş Sütçü İmam Üniversitesi Ziraat Fakültesi araştırma seralarında yapılmıştır. Araştırmada, Batı Akdeniz Araştırma Enstitüsü'nden temin edilen Akdarı, Beydarı ve Öğretmenoğlu tane sorgum çeşitleri kullanılmıştır. Çalışmada kullanılan kadmiyum $\mathrm{Cd}\left(\mathrm{CdSO}_{4} 8 / 3 \mathrm{H}_{2} \mathrm{O}\right)$ formunda ticari olarak temin edilmiştir.

\section{Bitkilerin yetiştirilmesi ve ağır metallerin uygulanması}

Deneme bölünmüş parseller deneme desenine göre kurulmuş olup toplam 54 saksı ( 3 çeşit $\times 1$ element $\times 6$ doz $\times 3$ tekrar) kullanılımışır. Saksılara 10 $\mathrm{kg}$ ağırlığında $4 \mathrm{~mm}$ elekten geçirilen topraklar doldurulmuştur. Deneme toprağı Kahramanmaraş Sütçü İmam Üniversitesi Avşar Kampüsü kampüs alanından temin edilmiş olup toprağa ait bazı özellikler; pH 7.33, tuz \%0.1, kireç \%0.71, organik madde $\% 0.6$ ve toplam kadmiyum $1.98 \mathrm{mg} \mathrm{kg}^{-1}$ ve alınabilir $0.126 \mathrm{mg} \mathrm{kg}^{-1}$ şeklindedir.

Bütün saksılara 3'er adet tohum ekimi yapılıp çıkıştan sonra sağlıklı olan fide bırakılıp diğerleri seyreltilmiştir. Gübre uygulaması (20 kg N ve $10 \mathrm{~kg}$ $\mathrm{P}_{2} \mathrm{O}_{5}$ oranı ile) kullanılan toprak miktarına göre hesaplanarak tartılıp uygulanmıştır. Bitkiler $15-20 \mathrm{~cm}$ boylandıklarında ağır metal uygulamaları yapılmıştır. Yüksek bir değer olan $300 \mathrm{mg} \mathrm{L}^{-1} \mathrm{Cd}$ kirlenmiş toprağı gösterir (Itoh ve Yumura, 1979; Kabata-Pendias, 2011). Bu değer kontamine topraklar için Kabata- 
Pendias ve Gondek, (1978) tarafından verilen 400 mg $\mathrm{L}^{-1} \mathrm{Cd}$ değerine yakındır (Kabata-Pendias, 2011). Ayrıca bazı ülkelerde işlenen tarım arazileri için kadmiyum kontaminasyonun ulaştığı değerler şu şekilde belirtilmiştir: Büyük Britanya; $1.5-167 \mathrm{mg} \mathrm{kg}^{-1}$, Polonya; 0.4-107 $\mathrm{mg} \mathrm{kg}^{-1}$ (Ellis ve Alloway, 1983 ve Umínska, 1988; Kabata-Pendias, 2011). Bilindiği üzere $\mathrm{pH}$ seviyesinin düşük olması Cd alımını artırırken yükselmesi bu alımı azaltabilmektedir. Kontamine topraklar için değerlerin bu kadar yükselebileceği ve deneme toprağının pH'sının hafif alkali sınıfında yer alması da göz önünde bulundurularak denemede kullanılan kadmiyum dozları belirlenmiştir. Kadmiyum miktarı kullanılan $10 \mathrm{~kg}$ toprak hacmine göre belirlenen dozlar neticesinde ppm olarak hesaplanmış, tartılmış ve saf su ile karıştırılarak saksılara uygulanmıştır. Günlük sulamalar toprağın tarla kapasitesine uygun olarak gerçekleştirilmiştir. Ekimler 2017 yılı Nisan ayında, hasatlar ise 2017 yılı Eylül ayında gerçekleştirilmiştir.

\section{Ölçümlerin yapılması}

Bitkiler 10 Eylül 2017 tarihinde sert olum döneminde elle hasat edilmiştir ve morfolojik ölçümler yapılmıştır. Morfolojik olarak bitki boyu, bitki gövde çapı, salkım uzunluğu, bin tane ağırlığı, yaprak oranı, gövde oranı ve salkım oranı belirlenmiştir.

İncelenen özelliklere ait verilerin istatistiksel analizleri, bölünmüş parseller deneme desenine uygun olarak varyans analizine tabi tutulmuştur. Elde edilen sonuçlar LSD testi ile karşılaştırılmıştır (SAS, 1999).

\section{Bulgular ve Tartışma}

Bazı tane sorgum çeşitlerinde (Akdarı, Beydarı ve Öğretmenoğlu), farklı dozlarda uygulanan Cd (kadmiyum) stresi altında morfolojik olarak meydana gelen değişiklikler incelenmiştir. Bitki boyuna ait değerler Tablo 1'de ve değişim grafiği Şekil 1'de verilmiştir. Cd dozlarının, bitki boyları varyans analiz sonuçlarına göre çeşit ve doz çok önemli $(p<0.01)$ iken çeşit $x$ doz interaksiyonu önemli $\quad(p<0.05)$ bulunmuştur.

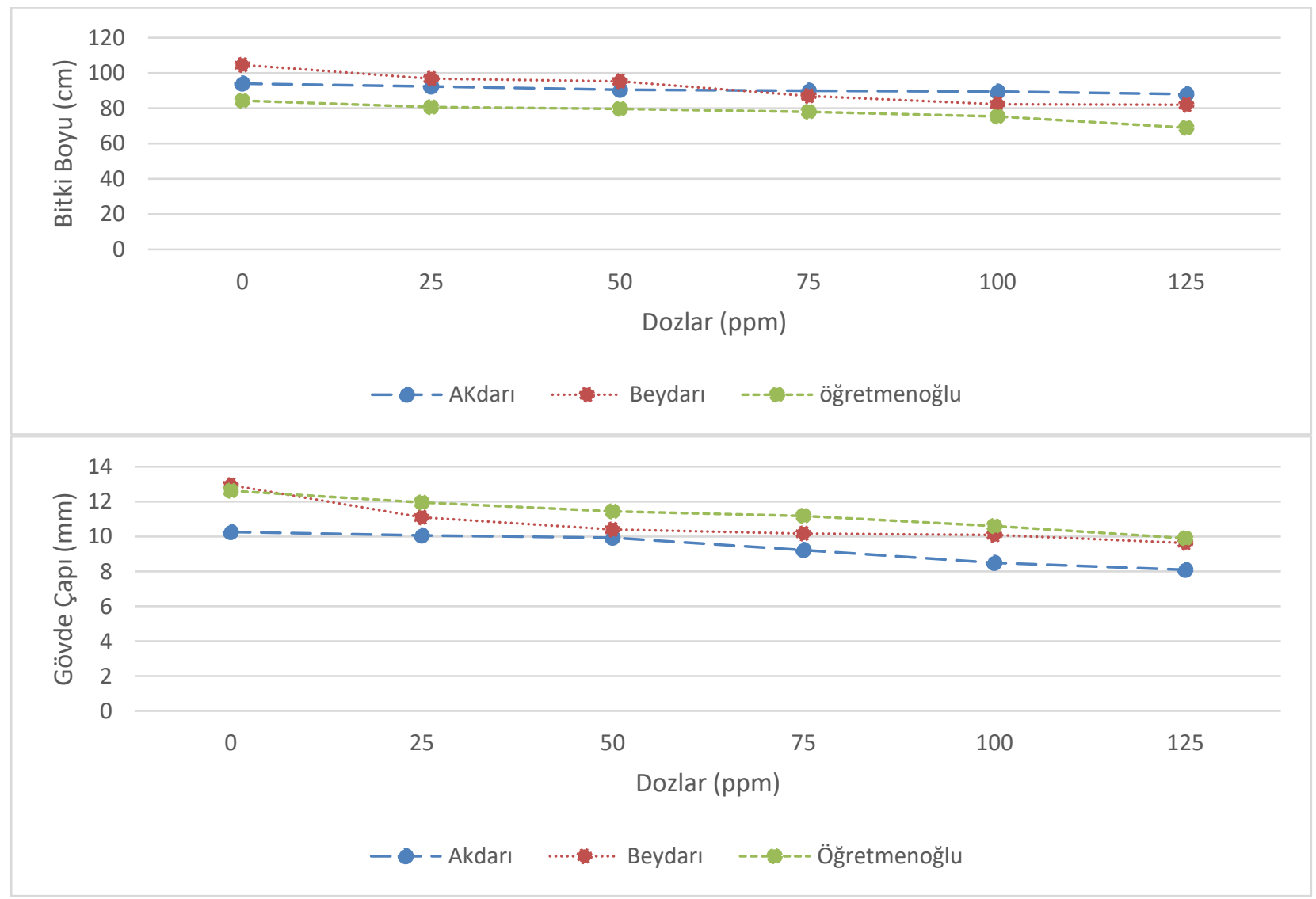

Şekil 1. Tane sorgum çeşitlerinin bitki boyu ve bitki gövde çaplarına ait değişim grafiği. 
Tane sorgum çeşitlerinin $\mathrm{Cd}$ stresinde bitki boylarında meydana gelen etkisi incelendiğinde, çeşitlerin ortalamasında en yüksek bitki boyunun (91.35 cm) Beydarı çeşidinde ve en düşük bitki boyunun ise Öğretmenoğlu $(77.83 \mathrm{~cm})$ çeşidinde ortaya çıktığı görülmüştür. Dozların ortalamasına baktığımızda ise, artan Cd dozlarının bitki boylarında azalmalara neden olduğu gözlenmektedir. En düşük bitki boyu $(79.67 \mathrm{~cm}) 125$ ppm Cd uygulamasından elde edilirken, en yüksek bitki boyu $(94.32 \mathrm{~cm})$ kontrol grubu bitkilerinden elde edilmiştir.

Cd uygulamasında en yüksek bitki boyu Akdarı, Beydarı ve Öğretmenoğlu çeşitlerinin kontrol uygulamasında elde edilirken, en düşük bitki boyunun tüm çeşitlerde en yüksek $\mathrm{Cd}$ dozu olan 125 ppm uygulamasından elde edildiği görülmüştür.
Cd uygulamasının bitki boyu gelişimini negatif yönde etkilediği anlaşılmaktadır. Wang ve ark. (2017) sorgum bitkisine farklı dozlarda (0-3-15 ppm) Cd uyguladıkları çalışmada bitki boyunun \%27.6-28.5 oranında azaldığını bildirmişlerdir. Zhang ve ark. (2002) Cd'u 0-1 ppm dozlarında buğday fidelerine uygulamış ve $0.3 \mathrm{mg} \mathrm{kg}^{-1}$ üzerindeki Cd miktarının bitki büyümesini inhibe ettiğini bildirmişleridir. Cd'nin büyümeyi engellediği ve dolayısıyla bitki boyu gelişimi üzerinde yaptığı olumsuz etki, yapılan çalışmalarla paralellik göstermektedir.

Bitki gövde çapına ait değerler Çizelge 2'de ve değişim grafiği Şekil 1'de verilmiştir. Bitki gövde çapları varyans analiz sonuçlarına göre çeşit ve doz çok önemli $(p<0.01)$ iken çeşit $x$ doz interaksiyonu önemsiz bulunmuştur.

Çizelge 1. Tane sorgum çeşitlerinin bitki boylarına $(\mathrm{cm})$ ait ortalama tablosu

\begin{tabular}{ccccc}
\hline Dozlar & \multicolumn{4}{c}{ Çeşitler } \\
\cline { 2 - 5 }$($ ppm) & Akdarı & Beydarı & Öğretmenoğlu & Ortalama \\
\hline 0 & $94 \pm 6.08 \mathrm{~B}-\mathrm{D} *$ & $104.61 \pm 3.07 \mathrm{~A}$ & $84.33 \pm 5.69 \mathrm{~F}-\mathrm{I}$ & $94.32 \mathrm{a} * *$ \\
25 & $92.37 \pm 2.03 \mathrm{~B}-\mathrm{E}$ & $96.8 \pm 2.03 \mathrm{~B}$ & $80.67 \pm 1.15 \mathrm{H}-\mathrm{J}$ & $89.94 \mathrm{ba}$ \\
50 & $90.5 \pm 0.5 \mathrm{~B}-\mathrm{F}$ & $95.33 \pm 3.21 \mathrm{BC}$ & $79.67 \pm 4.16 \mathrm{IJ}$ & $88.5 \mathrm{~b}$ \\
75 & $90 \pm 2.65 \mathrm{C}-\mathrm{F}$ & $87 \pm 3 \mathrm{E}-\mathrm{H}$ & $78 \pm 3.46 \mathrm{JJ}$ & $85 \mathrm{bc}$ \\
100 & $89.47 \pm 3.23 \mathrm{C}-\mathrm{F}$ & $82.33 \pm 4.04 \mathrm{G}-\mathrm{I}$ & $75.33 \pm 6.66 \mathrm{JK}$ & $82.38 \mathrm{C}$ \\
125 & $88 \pm 1.73 \mathrm{D}-\mathrm{G}$ & $82 \pm 4 \mathrm{G}-\mathrm{I}$ & $69 \pm 8 \mathrm{JK}$ & $79.67 \mathrm{c}$ \\
\hline Ortalama & $90.72 \mathrm{a} * *$ & $91.35 \mathrm{a}$ & $77.83 \mathrm{~b}$ & \\
\hline
\end{tabular}

** \% 1 *\% 5 önemli. Büyük harfler interaksiyon gruplarını, küçük harfler ortalama gruplarını ifade etmektedir.

Çizelge 2. Tane sorgum çeşitlerinin bitki gövde çaplarına ait ortalama tablosu

\begin{tabular}{ccccc}
\hline \multirow{2}{*}{ Dozlar $(\mathbf{p p m})$} & \multicolumn{4}{c}{ Çeşitler } \\
\cline { 2 - 5 } & Akdarı & Beydarı & Öğretmenoğlu & Ortalama \\
\hline 0 & $10.26 \pm 0.97$ & $12.94 \pm 0.58$ & $12.62 \pm 2.32$ & $11.94 \mathrm{a}^{* *}$ \\
25 & $10.06 \pm 0.65$ & $11.1 \pm 0.95$ & $11.95 \pm 2.11$ & $11.04 \mathrm{ba}$ \\
50 & $9.93 \pm 0.57$ & $10.4 \pm 1.42$ & $11.44 \pm 0.76$ & $10.59 \mathrm{bac}$ \\
75 & $9.22 \pm 0.45$ & $10.17 \pm 1.41$ & $11.18 \pm 0.94$ & $10.19 \mathrm{bc}$ \\
100 & $8.49 \pm 0.02$ & $10.09 \pm 1.06$ & $10.6 \pm 0.25$ & $9.73 \mathrm{bc}$ \\
125 & $8.09 \pm 1.1$ & $9.63 \pm 0.18$ & $9.9 \pm 1.09$ & $9.21 \mathrm{c}$ \\
\hline Ortalama & $9.34 \mathrm{~b}^{* *}$ & $10.82 \mathrm{ba}$ & $11.28 \mathrm{a}$ & \\
\hline
\end{tabular}

** \% 1 * \% 5 önemli. Büyük harfler interaksiyon gruplarını, küçük harfler ortalama gruplarını ifade etmektedir.

Tane sorgum çeşitlerinin $\mathrm{Cd}$ stresine karşı ortalama bitki gövde çaplarının $9.34 \mathrm{~mm}$ ile $11.28 \mathrm{~mm}$ arasında değiştiği ve en kalın gövde çapının Öğretmenoğlu çeşidinde, en ince gövde çapının ise Akdarı çeşidinde ortaya çıktığı görülmüştür.

Cd dozlarının artması ile ters orantılı olarak gövde çaplarının azaldığı belirlenmiştir. Ortalamada en ince gövde çapı (9.21 mm) 125 ppm Cd uygulamasından elde edilirken, en kalın gövde çapı (11.94 $\mathrm{mm})$ kontrol grubu bitkilerinden elde edilmiştir. Cd dozlarının artması bitkilerin gövde kalınlıklarını olumsuz etkilemiştir.

Cd uygulamasında en kalın bitki gövde çapı Beydarı ve Öğretmenoğlu çeşitlerinin 0 ppm dozlarından (kontrol) elde edilirken, en ince gövde çapı Akdarı çeşidinde 125 ppm Cd dozu uygulamasından elde edilmiştir.

Öktüren ve Sönmez (2006), toprakta Cd miktarının artması ile birlikte bitkinin klorofil metabolizmasının bozulduğunu ve azot kullanımında görevli olan $\mathrm{NO}_{2}^{-}$redüktaz ile $\mathrm{NO}_{3}^{-}$redüktaz 
enzimlerinin etkilerini azaltarak bitkinin azot kullanımını olumsuz etkilediğini belirtmişlerdir. Ağır metal stresinin devam etmesi ile hasar kök bölgesinden bitkinin gövdesine doğru ilerlemekte ve gövde gelişimini olumsuz etkilemektedir (Barceló ve Poschenrieder, 1990). Bu çalışmada da Cd dozlarının artmasıyla bitki çapı azalmış ve muhtemelen bu durumun bitkilerin $\mathrm{Cd}$ varlığından dolayı azot kullanımının sınırlanmasından ve köklerde başlayan ve gövdeye doğru ilerleyen fizyolojik aksaklıklardan kaynaklandığı düşünülmektedir.

Salkım uzunluğuna ait değerler Çizelge 3'te ve değişim grafiği Şekil 2'de verilmiştir. Bitki salkım uzunlukları varyans analiz sonuçlarına göre çeşit ve doz çok önemli $(p<0.01)$ iken çeşit $x$ doz interaksiyonu önemsiz bulunmuştur.

Çizelge 3. Tane sorgum çeşitlerinin salkım uzunluklarına $(\mathrm{cm})$ ait ortalama tablosu

\begin{tabular}{ccccc}
\hline \multirow{2}{*}{ Dozlar (ppm) } & \multicolumn{4}{c}{ Çeşitler } \\
\cline { 2 - 5 } & Akdarı & Beydarı & Öğretmenoğlu & Ortalama \\
\hline 0 & $16 \pm 1$ & $19.78 \pm 0.69$ & $18.7 \pm 0.89$ & $18.16 \mathrm{a}^{* *}$ \\
25 & $15.28 \pm 1.42$ & $19.8 \pm 1.06$ & $18.6 \pm 0.4$ & $17.89 \mathrm{a}$ \\
50 & $15.17 \pm 0.97$ & $18 \pm 0$ & $18.43 \pm 1.4$ & $17.20 \mathrm{ba}$ \\
75 & $15.1 \pm 0.46$ & $16.93 \pm 0.83$ & $17.2 \pm 1.31$ & $16.41 \mathrm{bc}$ \\
100 & $15.1 \pm 1.01$ & $16.35 \pm 1.25$ & $16.5 \pm 1.32$ & $15.98 \mathrm{bc}$ \\
125 & $14.97 \pm 1.42$ & $15.63 \pm 1.42$ & $15.3 \pm 0.89$ & $15.30 \mathrm{c}$ \\
\hline Ortalama & $15.27 \mathrm{~b}^{* *}$ & $17.75 \mathrm{a}$ & $17.46 \mathrm{a}$ &
\end{tabular}

** \% 1 * \% 5 önemli. Büyük harfler interaksiyon gruplarını, küçük harfler ortalama gruplarını ifade etmektedir.

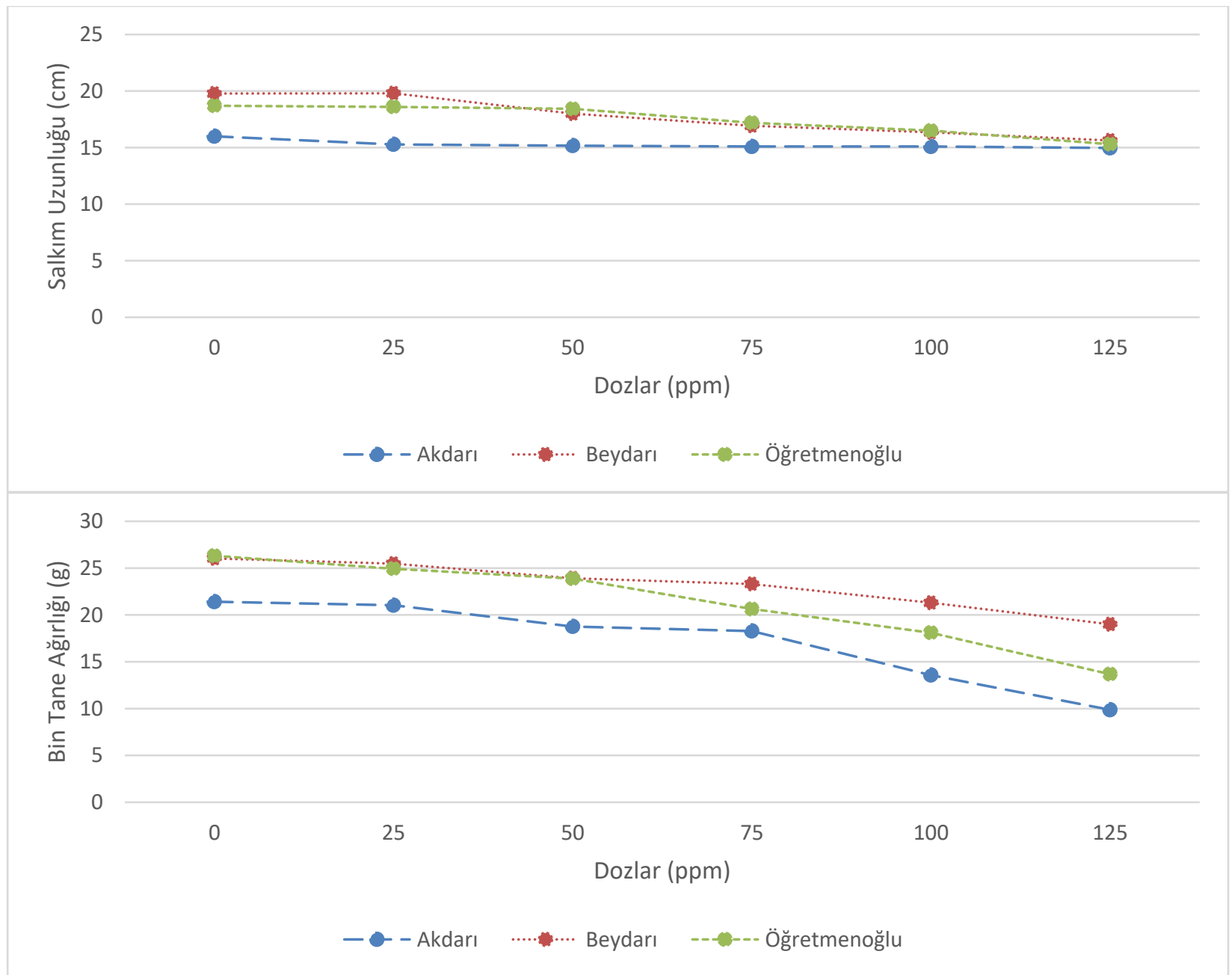

Şekil 2. Tane sorgum çeşitlerinin salkım uzunluğu ve bin tane ağırlığı değişim grafiği. 
Çeşitlerin salkım uzunlukları $15.27 \mathrm{~cm}$ ile 17.75 $\mathrm{cm}$ arasında değişiklik göstermiş ve en yüksek salkım uzunluğu Beydarı çeşidinde bulunurken en kısa uzunluğunu Akdarı çeşidinin salkımları oluşturmuştur.

Cd dozlarının artması salkım uzunluklarına ters yönde bir etkide bulunduğu ve salkım uzunluklarını azalttığı açıkça görülmektedir. En yüksek uzunluk $(18.16 \mathrm{~cm})$ kontrol uygulamasından elde edilirken, en düşük salkım uzunluğu $(15.30 \mathrm{~cm}) 125$ ppm Cd uygulamasından elde edilmiştir.

Çeşit $x$ doz interaksiyonu bakımından en uzun salkım uzunluğu Beydarı çeşidinin kontrol ve 25 ppm Cd dozlarından elde edildiği, bunu istatistiki olarak aynı grupta yer alan Öğretmenoğlu çeşidinin kontrol, 25 ve 50 ppm Cd uygulamalarının izlediği görülmektedir. En kısa salkım uzunluğu Akdarı çeşidinin 75, 100 ve 125 ppm Cd dozlarından elde edilmiştir. Dozların artmasına ters orantılı olarak salkım uzunlukları azalmıştır. Kullanılan çeşitler tane sorgum oldukları ve asıl unsurun salkım ve verim olduğu düşünüldüğünde salkım uzunluğu parametresinin önemi artmaktadır. Gür ve ark. (2004) ağır metallerin bitki dokularında yoğun olarak birikmesinin bitkilerin vejetatif ve generatif gelişimini olumsuz etkilediğini bildirirken, Long ve ark. (2002) bu birikimin ürün ve verim değerlerine negatif yönde etki ettiğini belirtmişlerdir.

Bin tane ağırlıklarına ait değerler Çizelge 4'te ve değişim grafiği Şekil 2'de verilmiştir. Cd dozlarının, bin tane ağırlıkları varyans analiz sonuçlarına göre çeşit ve doz çok önemli $(p<0.01)$ iken, çeşit $x$ doz interaksiyonu önemli $(p<0.05)$ bulunmuştur.

Çizelge 4. Tane sorgum çeşitlerinin bin tane ağırlıklarına (g) ait ortalama tablosu

\begin{tabular}{ccccc}
\hline \multirow{2}{*}{ Dozlar $(\mathbf{p p m})$} & \multicolumn{4}{c}{ Çeşitler } \\
\cline { 2 - 5 } & Akdarı & Beydarı & Öğretmenoğlu & Ortalama \\
\hline 0 & $21.41 \pm 1.95 \mathrm{D}-\mathrm{G} *$ & $26.03 \pm 1.08 \mathrm{AC}$ & $26.32 \pm 2.07 \mathrm{AB}$ & $24.59 \mathrm{a}^{* *}$ \\
25 & $21.03 \pm 2.31 \mathrm{D}-\mathrm{J}$ & $25.47 \pm 1.35 \mathrm{~A}-\mathrm{C}$ & $24.93 \pm 3.43 \mathrm{~A}-\mathrm{C}$ & $23.81 \mathrm{ba}$ \\
50 & $18.76 \pm 1.44 \mathrm{H}-\mathrm{K}$ & $23.92 \pm 2.41 \mathrm{~A}-\mathrm{D}$ & $23.88 \pm 1.61 \mathrm{C}-\mathrm{E}$ & $22.19 \mathrm{bc}$ \\
75 & $18.28 \pm 1.32 \mathrm{IK}$ & $23.3 \pm 1.14 \mathrm{~B}-\mathrm{F}$ & $20.63 \pm 0.47 \mathrm{~F}-\mathrm{I}$ & $20.74 \mathrm{C}$ \\
100 & $13.57 \pm 1.72 \mathrm{E}-\mathrm{I}$ & $21.3 \pm 0.61 \mathrm{~L}$ & $18.1 \pm 0.95 \mathrm{JK}$ & $17.66 \mathrm{~d}$ \\
125 & $9.87 \pm 1.69 \mathrm{M}$ & $19 \pm 1.37 \mathrm{G}-\mathrm{K}$ & $13.67 \pm 0.91 \mathrm{~L}$ & $14.18 \mathrm{e}$ \\
\hline Ortalama & $17.15 \mathrm{~b} * *$ & $23.17 \mathrm{a}$ & $21.26 \mathrm{ba}$ &
\end{tabular}

** \% 1 * \% 5 önemli. Büyük harfler interaksiyon gruplarını, küçük harfler ortalama gruplarını ifade etmektedir.

Çeşitlerin, bin tane ağırlıkları 17.15 g ile 23.17 g arasında değişiklik göstermiştir. En yüksek bin tane ağırlığı Beydarı çeşidinde iken en düşük bin tane ağırlığı Akdarı çeşidinde olmuştur.

Cd dozlarının artmasıyla birlikte bitkilerin bin tane ağırlıkları negatif etkiyle azalma göstermiştir. En yüksek bin tane ağırlığı (24.59 g) kontrol uygulamasından elde edilirken, en düşük bin tane ağırlığı (14.18 g) 125 ppm Cd uygulamasından elde edilmiştir. Cd doz artışı bin tane ağırlığını olumsuz etkilemiştir.

Çeşit $x$ doz interaksiyonuna baktığımızda, en yüksek bin tane ağırlığı Beydarı ve Öğretmenoğlu çeşitlerinin, kontrol ve 25 ppm Cd dozlarından elde edilirken, en düşük bin tane ağırlığı Akdarı çeşidinin 125 ppm Cd uygulamasından elde edilmiştir.

Çizelge 5. Tane sorgum çeşitlerinin gövde oranlarına (\%) ait ortalama tablosu

\begin{tabular}{ccccc}
\hline \multirow{2}{*}{ Dozlar (ppm) } & \multicolumn{4}{c}{ Çeşitler } \\
\cline { 2 - 5 } & Akdarı & Beydarı & Öğretmenoğlu & Ortalama \\
\hline 0 & $49.17 \pm 0.73 \mathrm{~F}^{*}$ & $51.61 \pm 0.72 \mathrm{EF}$ & $43.57 \pm 2.13 \mathrm{G}$ & $48.12 \mathrm{c}^{* *}$ \\
25 & $50.05 \pm 4.05 \mathrm{EF}$ & $56.75 \pm 3.47 \mathrm{~A}-\mathrm{C}$ & $56.51 \pm 3.39 \mathrm{~A}-\mathrm{D}$ & $54.44 \mathrm{~b}$ \\
50 & $50.7 \pm 1.42 \mathrm{EF}$ & $57.72 \pm 5.97 \mathrm{AB}$ & $57.82 \pm 2.46 \mathrm{AB}$ & $55.41 \mathrm{ba}$ \\
75 & $52.45 \pm 2.96 \mathrm{C}-\mathrm{F}$ & $57.03 \pm 3.46 \mathrm{AB}$ & $57.51 \pm 1.29 \mathrm{AB}$ & $55.66 \mathrm{ba}$ \\
100 & $52.23 \pm 2.26 \mathrm{D}-\mathrm{F}$ & $59.33 \pm 1.42 \mathrm{~A}$ & $57.14 \pm 1.33 \mathrm{AB}$ & $56.23 \mathrm{ba}$ \\
125 & $53.66 \pm 1.3 \mathrm{~B}-\mathrm{E}$ & $60.8 \pm 1.6 \mathrm{~A}$ & $59.37 \pm 4.09 \mathrm{~A}$ & $57.94 \mathrm{a}$ \\
\hline Ortalama & $51.38 \mathrm{~b}^{* *}$ & $57.21 \mathrm{a}$ & $55.32 \mathrm{ba}$ &
\end{tabular}

** \% 1 *\% 5 önemli. Büyük harfler interaksiyon gruplarını, küçük harfler ortalama gruplarını ifade etmektedir. 
Khan ve ark. (2006) 0, 25, 50 ve $100 \mathrm{mg} \mathrm{kg}^{-1} \mathrm{Cd}$ uyguladıkları 5 farklı buğday çeşidinde bin tane ağırlığının en yüksek doz olan $100 \mathrm{mg} \mathrm{kg}^{-1} \mathrm{Cd}$ seviyesinde en az olduğunu bildirmişlerdir. Bu sonuç çalışmamız ile paralellik göstermektedir. Ayrıca fotosentezinde tüm fizyolojik gelişme ve unsurların temeli olduğu düşünüldüğünde; Prasad (2005) ağır metallerin fotosentez üzerinde inhibe edici etki gösterdiği, terleme ve $\mathrm{CO}_{2}$ fiksasyonunu bozduğunu bildirmesi de çalışmamızda $\mathrm{Cd}$ stresinin bin tane ağırlığını (tane gelişimi ve verimini) olumsuz etkilediğini açıklayabilir.

Gövde oranlarına ait değerler Çizelge 5 'te ve değişim grafiği Şekil 3'te verilmiştir. Cd dozlarının, gövde oranları varyans analiz sonuçlarına göre çeşit ve doz çok önemli $(p<0.01)$ iken çeşit $x$ doz interaksiyonu önemli $(p<0.05)$ bulunmuştur.

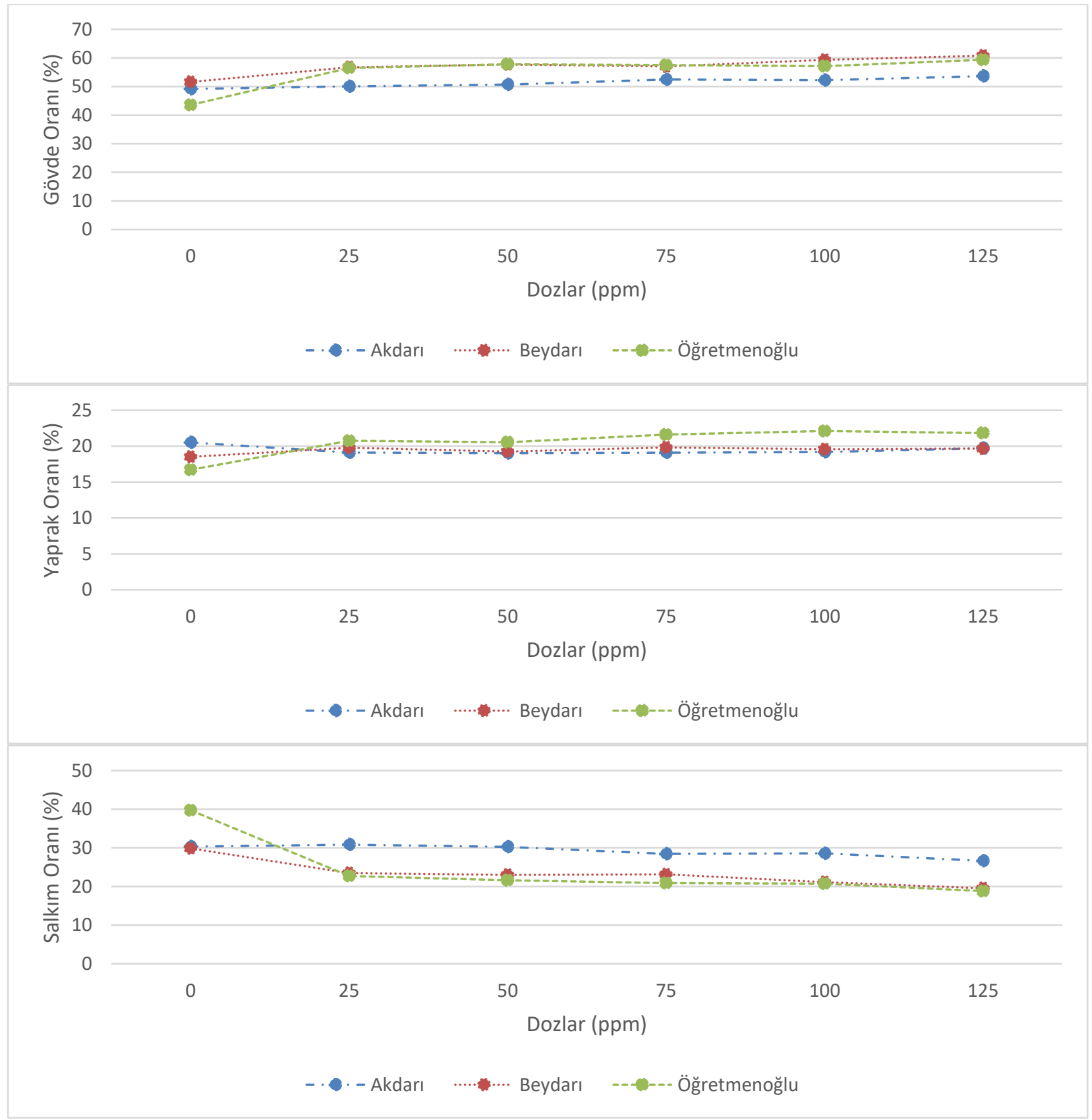

Şekil 3. Tane sorgum çeşitlerinin gövde uzunluğu, yaprak oranı ve salkım oranı değişim grafiği. 
Çeşitlerin, gövde oranları \%51.38 ile \%57.21 arasında değişiklik göstermiştir. En yüksek gövde oranı Beydarı çeşidinde iken, en düşük gövde oranı ile Akdarı çeşidinde olmuştur.

Cd dozlarının artmasına paralel olarak gövde oranları da artış göstermiştir. En yüksek gövde oranı (\%57.94) 125 ppm Cd uygulamasından elde edilirken, en düşük gövde oranı (\%48.12) 00 ppm $\quad \mathrm{Cd}$ uygulamasından elde edilmiştir.

Çeşit $x$ doz interaksiyonuna baktığımızda, en yüksek gövde oranı Beydarı çeşidinin 100 ve 125 ppm dozları ile Öğretmenoğlu çeşidinin 125 ppm dozundan elde edilmiştir. En düşük gövde oranı 0 ppm dozunda Öğretmenoğlu çeşidinden elde edilmiştir.

Cd stresinin bitkinin gövde oranını artırmasına neden olduğu görülmüştür. Cherney ve ark. (1990) bitkilerin morfolojik yapısı ve bitkinin tamamı içindeki morfolojik organların oranının; bitkinin besin içeriğini ve yem olarak tüketilebilirliğini etkilediğini bildirmişlerdir. Bu çalışmadaki tane sorgum çeşitlerinin Cd stresi kaynaklı taneye dair parametreleri (tane verimi, bin tane ağırlığı, salkım oranı ve salkım uzunluğunu) azalttığı sonucuna göre, bitki kısımlarının tüm bitkiye olan oranında salkım oranının azalması doğal olarak gövde oranını arttırmış olabilir.

Yaprak oranlarına ait değerler Çizelge $6^{\prime}$ da ve değişim grafiği Şekil 3'te verilmiştir. Cd dozlarının, yaprak oranları varyans analiz sonuçlarına göre çeşit önemli $(p<0.05)$ iken doz ve doz $x$ çeşit interaksiyonu önemsiz bulunmuştur.

Çizelge 6. Tane sorgum çeşitlerinin yaprak oranlarına (\%) ait ortalama tablosu

\begin{tabular}{ccccc}
\hline \multirow{2}{*}{ Dozlar (ppm) } & \multicolumn{4}{c}{ Çeşitler } \\
\cline { 2 - 5 } & Akdarı & Beydarı & Öğretmenoğlu & Ortalama \\
\hline 0 & $20.52 \pm 0.69$ & $18.51 \pm 0.95$ & $16.71 \pm 1.01$ & 18.58 \\
25 & $19.11 \pm 2.42$ & $19.78 \pm 1.64$ & $20.75 \pm 1.78$ & 19.88 \\
50 & $19.03 \pm 3.09$ & $19.25 \pm 2.11$ & $20.55 \pm 0.95$ & 19.61 \\
75 & $19.1 \pm 1.03$ & $19.83 \pm 0.3$ & $21.61 \pm 0.37$ & 20.18 \\
100 & $19.19 \pm 0.57$ & $19.57 \pm 0.73$ & $22.11 \pm 0.71$ & 20.29 \\
125 & $19.71 \pm 2.58$ & $19.66 \pm 1.56$ & $21.83 \pm 3.34$ & 20.40 \\
\hline
\end{tabular}

Ortalama

$19.45 b^{*}$

$19.43 \mathrm{~b}$

20.59 a

** \% 1 *\% 5 önemli. Büyük harfler interaksiyon gruplarını, küçük harfler ortalama gruplarını ifade etmektedir.

Çeşitlere ait yaprak oranları ortalamaları \%19.43 ile \%20.59 arasında değişiklik göstermiştir.

Cd dozlarına ait bitkinin yaprak oranı ortalamaları da \%18.58 ile \%20.4 arasında değişiklik göstermiştir.

Çeşit $\mathrm{x}$ doz interaksiyonuna baktığımızda ise, en yüksek yaprak oranı Öğretmenoğlu çeşidinin 100 ppm dozundan ve en düşük yaprak oranı yine Öğretmenoğlu çeşidinin kontrol uygulamasından elde edilmiştir.

Yaprak oranlarında bir değişim gözlenmemesi, Skórzynska-Pilot ve Baszynski (1997) yaptıkları bir çalışmada $\mathrm{Cd}$ yoğunluğunda genç bitkilerde fotosentetik aktivitenin neredeyse değişmediğini belirtmeleriyle paralel olarak çalışmamızda da yaprak oranlarının aynı ortalama grubunda yer aldığı düşünülebilir. Ancak çeşitlerin kendi içerisinde dozların artmasına karşılık; yaprak oranında düzenli bir artış, azalış ya da değişim göstermemesi doz ve bitki arasındaki fizyolojik değişim sebebi ve seviyesi ile ilgili olabilir çünkü yapılan çalışmalarda Cd'nin olumlu ve olumsuz etkilerinin olabileceği sunulmuştur. Elementin çeşit ve yoğunluğuna bağlı olarak yaprak alanının küçülmesi, klorofil kaybı gözlemlenebilmektedir (Benavides ve ark., 2005; Lombardı ve Sebastiani, 2005). Zhang ve ark. (2002) ise düşük dozlarda Cd'nin büyüme üzerine olumlu bir etkisinin olduğunu söylemişlerdir.

Salkım oranlarına ait değerler Çizelge 7'de ve değişim grafiği Şekil 3'te verilmiştir. Cd dozlarının, çeşitlerin salkım oranına etkisinin varyans analiz sonuçlarına göre doz, çeşit ve doz x çeşit interaksiyonu çok önemli $(p<0.01)$ bulunmuştur.

Çeşitlerin salkım oranları \%23.36 ile \%29.18 arasında değişiklik göstermiş ve en yüksek salkım oranı Akdarı çeşidinden, en düşük salkım oranı Beydarı çeşidinden elde edilmiştir.

Cd dozlarının bitkilerin salkım oranlarına etkisi incelendiğinde, doz artışına ters orantılı olarak bitkilerin salkım oranı azalış göstermiş ve en düşük salkım oranı (\%21.66) 125 ppm Cd uygulamasından elde edilirken, en yüksek salkım oranı (\%33.30) 0 ppm Cd uygulamasından elde edilmiştir.

Çeşit x doz interaksiyonuna baktığımızda, en yüksek salkım oranı Öğretmenoğlu çeşidinin kontrol uygulamasında ve en düşük salkım oranı ise aynı çeşidin 125 ppm dozunda elde edilmiştir. 
Cd stresi tane sorgum çeşitlerinin salkım oranlarını olumsuz yönde etkilemiş ve stresin artmasıyla birlikte bitkilerin salkım oranları azalma göstermiştir. Kara (2016) tane verimi ile fizyolojik özellikler (fotosentez hızı, stoma iletkenliği vb.) arasında pozitif ilişkilerin var olduğunu bildirmiştir. Kennedy ve Gonsalves (1987) ise ağır metallerin toksisite gösterdiği bitkilerde meydana gelen fizyolojik problemler arasında; fotosentez, enzim aktivitesi, stoma mobilitesinin sayılabileceğini belirtmişlerdir.

Çizelge 7. Tane sorgum çeşitlerinin salkım oranlarına (\%) ait ortalama tablosu

\begin{tabular}{ccccc}
\hline \multirow{2}{*}{ Dozlar (ppm) } & \multicolumn{4}{c}{ Çeşitler } \\
\cline { 2 - 5 } & Akdarı & Beydarı & Öğretmenoğlu & Ortalama \\
\hline 0 & $30.31 \pm 1.4 \mathrm{~B} * *$ & $29.87 \pm 1.24 \mathrm{BC}$ & $39.72 \pm 1.44 \mathrm{~A}$ & $33.30 \mathrm{a}^{* *}$ \\
25 & $30.84 \pm 2.43 \mathrm{~B}$ & $23.48 \pm 1.99 \mathrm{DE}$ & $22.74 \pm 1.72 \mathrm{EF}$ & $25.68 \mathrm{~b}$ \\
50 & $30.26 \pm 1.93 \mathrm{~B}$ & $23.02 \pm 4.01 \mathrm{D}-\mathrm{F}$ & $21.63 \pm 1.52 \mathrm{E}-\mathrm{G}$ & $24.97 \mathrm{~b}$ \\
75 & $28.44 \pm 3.99 \mathrm{BC}$ & $23.14 \pm 3.16 \mathrm{DE}$ & $20.89 \pm 1.06 \mathrm{E}-\mathrm{G}$ & $24.16 \mathrm{cb}$ \\
100 & $28.58 \pm 1.7 \mathrm{BC}$ & $21.11 \pm 0.86 \mathrm{E}-\mathrm{G}$ & $20.75 \pm 2 \mathrm{E}-\mathrm{G}$ & $23.48 \mathrm{cb}$ \\
125 & $26.63 \pm 1.53 \mathrm{CD}$ & $19.54 \pm 1.01 \mathrm{FG}$ & $18.81 \pm 0.81 \mathrm{G}$ & $21.66 \mathrm{c}$ \\
\hline Ortalama & $29.18 \mathrm{a}^{* *}$ & $23.36 \mathrm{~b}$ & $24.09 \mathrm{~b}$ &
\end{tabular}

** \% 1 *\% 5 önemli. Büyük harfler interaksiyon gruplarını, küçük harfler ortalama gruplarını ifade etmektedir.

\section{Sonuç ve Öneriler}

Araştırma sonuçlarına göre $\mathrm{Cd}$ dozlarının artmasıyla birlikte, bitki boyunun, bitki gövde çapının, bin tane ağırlığının, salkım uzunluğunun ve salkım oranının düzenli bir şekilde azaldığı gözlemlenirken, gövde oranının ise $\mathrm{Cd}$ (kadmiyum) dozlarının artmasına paralel olarak arttığı belirlenmiştir. Çalışmada kullanılan tane sorgum çeşitlerinin (Akdarı, Beydarı ve Öğretmenoğlu) kadmiyum dozlarından 25 ppm ve üzerindeki seviyelerde olumsuz etkilendiği görülmüş ve toprak $\mathrm{pH}^{\prime} \mathrm{s}$ I da göz önünde bulundurulduğunda hafif alkali topraklar için 25 ppm ve daha yüksek dozlarda sorgum bitkisinin morfolojik yönden olumsuz etkilendiği ve verim amaçlı yetiştiricilik için uygun olmadığı düşünülmektedir.

\section{Teşekkür}

¥: Bu çalışma, Bingöl Üniversitesi, Bilimsel Araştırma Projeleri Koordinasyon Birimi BAPZF.2017.00.008 No'lu Projesi ile desteklenmiş ve Hava Şeyma YILMAZ'ın doktora tezinden hazırlanmıştır.

\section{Kaynaklar}

Alloway BJ, Steinnes E 1999. Anthropogenic Additions of Cadmium to Soils. In: McLaughlin MJ, Singh BR (eds), Cadmium in Soils and Plants, Kluwer Academic Publishers, Dordrecht.

Anonymous, 1995. Sorghum and Millets in Human Nutrition. FAO Food and Nutrition Series, No:27, Rome, Italy. www.fao.org/inpho/vlibrary/t0818e/t0818e0 0.htm (Erişim Tarihi: 10.02.2019).
Barceló, J., Poschenrieder, C. 1990. Plant water relations as affected by heavy metal stress: $A$ review. J. Plant Nutr. 13: 1-37.

Benavides, M.P., Gallego, S.M., Tomaro, M.L. 2005. Cadmium toxicity in plants, Braz. J. Plant Physiol., 17(1): 21-34.

Cherney, D.J.R., Mertens, D.R., Moore, J.E. 1990. Intake and digestibility by wethers as influenced by forage morphology at three levels of forage offering. Journal of Animal Science, 68(1): 4387-4399.

Dowling, L.F., Arndt, C., Hamaker, B.R. 2002. Economic Viability of High Digestibility Sorgum as Feed for Market Broilers. Agronomy Journal, 94: 1050-1058.

Ellis, R.H., Alloway, B.J. 1983. Factors affecting availability of $\mathrm{Cd}, \mathrm{Pb}$ and $\mathrm{Ni}$ in soils amended with sewage sludge, in Heavy Metals in the Environment, Vol. 1, CEP Consult., Edinburgh, 1: 358, 1983.

Gualtire, M., Rapaccini, S. 1990. Sorghum Grain Poultry Feeding. World's Poultry Science Journal, 46: 246-254.

Gür, N., Topdemir, A., Munzuroğlu, Ö., Çobanoğlu, D. 2004. Ağır metal iyonlarının $\left(\mathrm{Cu}^{+2}, \mathrm{~Pb}^{+2}, \mathrm{Hg}^{+2}\right.$, $\mathrm{Cd}^{+2}$ ) Clivia sp. bitkisi polenlerinin çimlenmesi ve tüp büyümesi üzerine etkileri. F.Ü. Fen ve Matematik Bilimleri Dergisi, 16(2): 177-182.

Itoh, S., Yumura, Y. 1979. Studies On the Contamination of Vegetable Crops by Excessive Absorption Of Heavy Metals. Bull. Veg. Ornamental Crops Res. Stn., 6a, 123, 1979 (Ja). 
Kabata-Pendias, A. 2011. Trace Elements in Soils and Plants. 4th edn. CRC Press, Boca Raton.

Kabata-Pendias, A., Gondek, B. 1978. Bioavailability of Heavy Metals In The Vicinity of A Copper Smelter, in Trace Subst. Environ. Health, Vol. 12, Hemphill, D. D., ed., University of Missouri, Columbia MO, 523, 1978.

Kahvecioğlu, Ö., Kartal G., Güven A., Timur S. 2007. Metallerin Çevresel Etkileri -I. (erişim adresi: https://metalurji.org.tr (Erişim tarihi: 29.01.2019).

Kara, R. 2016. Evaluation of flag leaf physiological traits of triticale genotypes under eastern Mediterranean conditions. Turk J. Field Crops, 21(1): 67-78.

Kennedy, C.D., Gonsalves, F.A.N. 1987. The action of divalent zinc, cadmium, mercury, copper and lead on the trans-root potential and efflux of excised roots. J.Exp. Bot., 38: 800-817.

Khan, N.A., Ahmad, I., Singh, S., Nazar, R. 2006. Variation in growth, photosynthesis and yield of five wheat cultuvars exposed to Cd stress. Word J. of Agricultural Sci., 2(2): 223-226. ISSN 1817-3047.

Kriegshauser, T.D., Tuinstra, M.R., Hancock, J.D. 2006. Variation in nutritional value of sorghum hybrids with contrasting seed weight characteristics and comparison with maize in broiler chicks. Crop Science, 46: 695-699.

Lombardi, L., Sebastiani, L. 2005. Copper toxicity in Prunus cerasifera: Growth and antioxidant enzymes responses of in vitro grown plants. Plant Sci., 168: 797-802.

Long, X.X., Yang, X.E., Ni, W.Z. 2002. Current Status and perspective on phytoremediation of heavy metal polluted soils. Journal of Applied Ecology, 13: 757-762.

Öktüren, Asri, F., Sönmez, S. 2006. Ağır Metal Toksisitesinin Bitki Metabolizması Üzerine Etkileri. Akdeniz Üniversitesi Toprak Bölümü, 10s, Antalya.

Prasad, M.N.V. 2005. Cadmium toxicity and tolerance in vascular plants. Environ. Exp. Bot., 35:525545.

SAS, 1999. SAS User's Guide: Statistic. Statistical Analysis Systems Institute Inc., Cary, NC.

Skórzynska-Pilot, E., Baszynski, T. 1997. Differences in sensitivity of the photosynthetic apparatus in Cd-stressed runner bean plants in relation to their age. Plant Sci., 128: 11.

Stresty, T.V.S., Madhava Rao, K.V. 1999. Ultrastructural alterations in response to zinc and nickel stress in the root cell of pigeonpea, Environ Exp Bot., 41: 3-13.

Umínska, R. 1988. Assessment of Hazardous Levels of Trace Elements to Health in Contaminated Soils of Poland, Inst. Medycyny Wsi, Warszawa, 188, 1988 (Po).

Wang, X., Chen, C., Wang, J. 2017. Cadmium phytoextraction from loam soil in tropical southern China by Sorghum bicolor. Internatıonal Journal of Phytoremediatıon, 19(6): 572-578.

Wierzbicka M.H., Przedpelska E., Ruzik R. 2007. Comparison of the toxicity and distribution of cadmium and lead in plant cells. Protoplasma, 231: 99-111.

Zhang, G, Fukami, M., Sekimoto, H. 2002. Difference between Two Wheat Cultivars in $\mathrm{Cd}$ and Mineral Nutrient Uptake under Different Cd Levels. Pub Med, PMD:12222053 [PubMedindexed for MEDLINE].2002 Apr, 13(4): 454-8. 